\title{
Efectiveness Of Experiential Learning Models In Learning Arts Culture And Skills Of Elementary School Students
}

\author{
Awaluddin Muin ${ }^{1}$, Hasbi Rauf ${ }^{2}$ \\ \{awalmuin@gmail.com ${ }^{1}$, hasbir@gmail.com² \\ 1,2PGSD Universitas Negeri Makassar, Indonesia
}

\begin{abstract}
The problem studied is to describe the learning of arts and culture and the skill with experiential learning models. This type of research is grounded theory research. The approach used is purely qualitative. This research was conducted in Class V of 2018. Subjects in this study were students of class $\mathrm{V}$ B of elementary school, totaling 39 people consisting of 14 men and 25 women. Collecting data in this study using observation sheets, questionnaires, interviews, and documentation. Data analysis technique is done by data reduction, data presentation, and drawing conclusions. The results of the study note that SBK learning requires direct experience to achieve optimal learning outcomes (motor). The experiential learning model of students is directly involved in the practice of playing music with their motor skills. The use of experiential learning models is effective in learning the art of music in class V B SD Inpres 5/81 Bajoe Tanete Riattang Timur District Bone District.
\end{abstract}

Keywords: effectiveness, experiential learning, cultural arts and skills, music art

\section{Introduction}

The development of an increasingly rapid era led to demands for progress in various fields. One very important field is education, in order to increase the empowerment of a country. In this connection, the role of education is very important in educating the life of the nation and improving the quality of a country's human resources. As for the efforts made by the government to overcome this, namely the provision of education that is tiered according to the age level of the child / student. Every level of education experienced by students becomes a valuable experience in students. One of the language fairies states that "experience is the best teacher". The sentence implies that in life it takes experience stock. Elementary School (SD) which becomes the first level of acquiring student experience has a variety of studies with learning characteristics that become its special characteristics.

One of the studies at elementary school level is art with the characteristics of appreciation and work. In line with the opinion of "Art education is one of the determining factors in shaping the personality of children".[1] Art education which is very important demands a reference in its implementation, so that one reference is called curriculum. To direct education, especially the arts family. There are two curriculums that are still in use in the 2017/2018 school year, namely the Education Unit Level Curriculum (KTSP) in 2006, art in elementary school is 
entitled the subject of Arts and Culture and Skills (SBK). And the 2013 curriculum with the title art subjects namely Arts and Crafts (SBD P). Both curriculums contain study materials of various types and forms of fine arts, music, dance, drama, and skills. However, SBdP is studied in an integrated manner. It is different from SBK which thoroughly covers hand study materials and a sense of beauty that arises from a variety of artistic activities.

SBK has an important role in developing basic motor competencies that must be in accordance with periods of development that are innocent, unique, creative, spontaneous and dynamic. So that the provision of learning experiences at this time is the best time because it can develop the ability of students both physically and psychologically in a whole and meaningful way. The need for experience to work through one branch of art that is the art of music with musical instrument material. States that "music is an element of art which contains sound elements. Sounds generated from various musical instruments must be different " [2]. The music in question is a part of art that is synonymous with sound from vocal processing, musical instruments, or a combination of vocals and musical instruments.

Music art education in elementary schools certainly will not escape learning and learning activities. Various techniques, methods, approaches, models and strategies exist and have been adapted to learning materials and subjects. The use of strategies in a teaching so that in delivering certain teaching materials can be delivered properly by the teacher. In afcordance with the results of that: [3]

The method, strategy, or learning activity carried out by the teacher should be something that is truly appropriate and meaningful, to obtain maximum results in accordance with the stages of student development, the strategies that the teacher must use must be appropriate.

Learning in elementary schools specifically in SBK subjects is the subject of the art of music with a very closely related model, experiential learning. This model is a model with the aim of student centered oriented (student-centered learning). So that with this model learning has an activeness effect on students and teachers becoming providers of conducive learning conditions. So seeing this it is necessary to hold research to understand and describe the use of experiential learning models in SBK (music art) subjects V B SD Inpres 5/81 Bajoe.

\subsection{Effectiveness}

Effectiveness comes from the effective word that there is an effect (effect, effect, impression) Big Indonesian Dictionary (KBBI). That "basically effectiveness is aimed at answering the question of how far the learning objectives have been achieved by students".[4] Learning objectives are generally to learn students that need to be measured. States "effectiveness is the relationship between outputs with goals or objectives that must be achieved"[5]. Said to be effective if in the process and results / outcomes can be in accordance with the objectives. In line with that "effectiveness is a basic element to achieve the goals or targets that have been determined in every organization, activity or program" effectiveness means effectiveness which means influential circumstances, memorable things, success.[6]

Learning can be said to be successful in terms of process and results. In terms of the process that is visible learning activities of active students, both mental, physical and social. As for the terms of the results appear from the behavior of students who are positive. Determination of dimensions of learning effectiveness according to [7]. 
Two characteristics of effective learning, namely a. characteristics of effective teachers in the learning process, namely teachers who have the ability in curriculum development; $b$. Characteristics of students who are effective in the learning process are students who are flexible and active in utilizing different strategies and approaches for different contexts and goals.

\subsection{Experiental Learning Model}

1) Understanding Experiental Learning Learning Model

Experiential Learning Theory (ELT), which later became the basis of experiential learning models, was developed by David Kolb around the early 1980s. This model emphasizes a holistic learning model in the learning process. In experiential learning, experience has a central role in the learning process. It is this emphasis that distinguishes ELT from other learning theories. "Experiential learning" is to distinguish between cognitive learning theories that tend to emphasize cognition more than affective, and behavior learning theories that eliminate the role of subjective experience in the learning process, experiential learning models are efforts to build knowledge through the transformation of experience according to [8]

"Successful experiential learning does not only involve participants in activities. They help the participants bring up the meaning of the activity ... "The context of learning and learning that reflects in-depth experiences by involving students with meaning so that new understanding or learning process emerges [9]. Experience-based learning utilizes experience to build understanding in the realm of attitudes, knowledge, and skills. the experience gained by the students from the learning process must be directed. The mindset of those who are usually not able to interpret the meaning of the experience they have gained so that new understanding or learning processes emerge from the students.

2) Benefits of Experiental Learning Learning Models

Benefits are things that are the purpose of what is done, in other words mean the benefits obtained. Experiental learning model in learning certainly has advantages in its application. There are 3 benefits in the Experiental learning model, namely "changing cognitive structures, student attitudes and existing student skills"[10].

\section{3) Experiental Learning Stage}

Experiental learning in its implementation has the stages that characterize the model. The intended characteristic is before and after learning that gives students direct experience without losing the teacher's supervision of the learning process they experience. The learning procedure in experiential learning consists of 4 stages, namely "the stage of real experience; reflection observation stage; conceptualization stage; and implementation phase " [10].

\section{Learning in elementary school}

Learning is a process carried out by teachers and students who aim to provide learning experiences that are new in nature and the development of things that already exist before. Law No.20 of 2003 concerning National Education System Chapter I Article 1 "Learning is the process of interaction of students with educators and learning resources in a learning environment". In addition, learning is a series of events that affect learning so the learning process can take place easily [10]. "Learning is a system, which consists of various components that are interconnected with one another. These components include: objectives, materials, methods and evaluations. Based on some of these 
definitions, it can be concluded that learning is an interaction that occurs between students and educators that are useful for gaining learning and teaching experiences consisting of various ways in their implementation [11]

\section{Learning Characteristics}

Educative learning is an interaction that is done consciously and has the aim to educate in order to lead students towards maturity. The educational process has the following characteristics: 1) there is a goal to be achieved; 2) there is a message to be transferred; 3) there are students; 4) there is a teacher; 5) there is a method; 6) there is a situation; 7) there is an assessment.

\section{Characteristics of Change in Learning Outcomes Behavior}

Changes that occur in learning activities are not all considered as changes in learning outcomes. There are several behavioral traits that can be categorized as follows: 1) Changes that are based and intentional; 2) Continuous change; 3) Functional changes; 4) Changes that are continuous; 5) Changes that are permanent; 6) Changes in purposeful or directed learning; 7) Change covers all aspects of behavior [12]

\section{Cultural Arts and skills}

Art / se'ni /; smooth (about palpation); small and delicate; thin and smooth, KBBI. In addition, etymologically the word art comes from the Sanskrit Sani language which means worship, offerings, and service. In English, art is called art which comes from the Latin artem which has the same meaning. Art is also explained that a conscious human effort to create a work that has forms that are pleasing to those who see it, both directly and indirectly [12]. The word culture comes from the Sanskrit language that is Buddha, which is the plural form of Buddha (mind or reason) interpreted as matters relating to mind, and human reason. It could also be interpreted as cultivating land or farming, KBBI. Culture can also be seen as a setting for a type of human being, normative in nature for certain groups, and will give birth to a certain lifestyle in a typical and meaningful way of being with other groups, which is from the background of human work behavior able to contribute to the realization of a lifestyle that has characteristics [12]

Skills come from skilled / te'ram'pil /: proficient in completing assignments; able and pressure; so skills / ke'te'ram'pil'an /: skills to complete tasks, KBBI. Skills are synonymous with the word deft. Therefore, skill is a form of skill found in individuals to pour students' soul of creativity.

Based on the understanding of art, culture and previous skills. So, cultural arts and skills are the work of humans who have the aesthetic value of the form of creation, taste and intention. In KTSP, cultural arts subjects consisting of fine arts, music, dance, and theater have goals that include: 1) understanding the concept and importance of cultural arts; 2) understand the attitude of appreciation for cultural arts, 3) display creativity through cultural arts, 4) display participation in cultural arts at local, regional and global levels. Each branch of art has its own scope based on the field / media and character of the art. "Specifically SBK subjects include aspects of: 1) fine arts; 2) the art of music; 3) dance; 4) drama art; 5) skills "[1]

\section{Music Art}


Art music consists of 2 words, art and music. Art is a product of creation, taste and intention as outlined in several forms of means. While music comes from the Greek "mousikos", symbolizing the god of beauty who mastered the fields of science and art. Music is the science or art of composing tones or sounds in sequence, combination, and temporal relationships to produce compositions (sounds) that have unity and continuity, "music is an element of art which contains [2]

\section{Music Elements}

There are several elements of musical art, namely rhythm, melody, harmony, tempo [13]. From these 4 elements can be described as follows: Rhythm in music is formed from a combination of a group of sounds; a melody is an arrangement of tones (regular sounds and vibrations) that sound sequentially and rhythmically, and use an idea. A harmony or chorus is the sound of a song or musical game that uses two or more tones, which have different pitches and we hear simultaneously; Tempo is the speed of a song, and changes in the speed of a song.

\section{The Nature of Teaching Music in Elementary School}

Music teaching is teaching about musical ability by understanding the meanings and meanings of the elements of music that make up a song or musical composition, which is conveyed to students through musical experience activities.Teaching music in elementary school is part of the overall education of children at the stage of their personal formation in order to lead to the formation of a fully Indonesian man [14]. To carry out teaching music in elementary school should have the formulation of the objectives of teaching music in elementary school, so that in practice it can always be guided by the objectives to be achieved.

The process of learning art and culture (music), one of the aspects that needs attention is the use of experiential learning models that are appropriate for the concept of learning in students. Learning Cultural Arts and Skills (SBK) which leads to experiential learning models in music art learning that produce musical performances from various musical instruments and evaluation of students' musical works with experiential learning models. Music performance is also an evaluation of music art learning with experiential learning models such as the following plot:

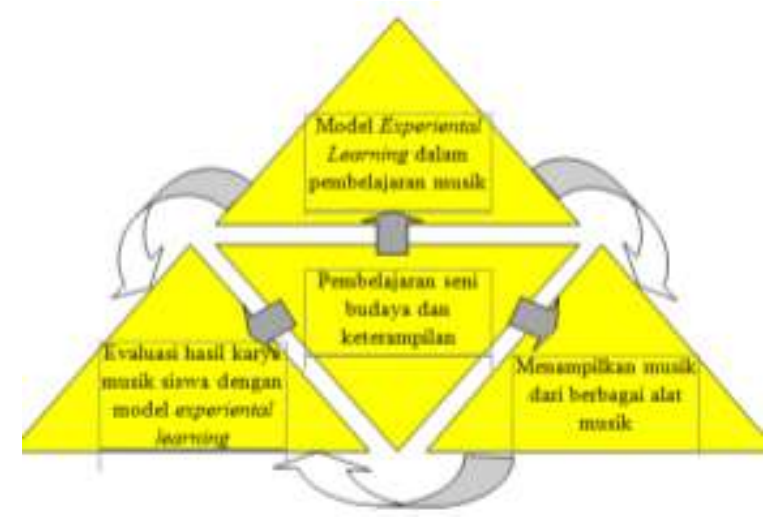

Figure 1. Experimental learning model Class V B SD Inpres 5/81 Bajoe 


\section{Focus of the Problem}

Based on the context of the problem that has been described, the focus of the problem in this research is whether the experiential learning model is effectively used in arts and culture subjects and skills in music art in class V B SD Inpres 5/81 Bajoe, Tanete Riattang Timur District?

\section{METHODS}

\subsection{Research Approaches and Types}

\section{Research Approach}

The approach used in this study is a qualitative approach. This approach is used to describe or describe concepts from experiential learning models. The use of this model has become the majority of class V B teachers in teaching. So it is necessary to look for the usefulness of experiential learning theory models in music art lessons. This research emphasizes the natural and holistic condition of objects. Researchers carry out a comprehensive process of finding and analyzing, analyzing and interpreting visual and narrative data. The researcher acts as a key instrument that collects data with various types of research instruments.

\section{Types of research}

This study uses a type of grounded theory research. The experiential learning variable (experiential learning) is the basis for the theory. So that researchers involved in it to explore, identify and elevate meanings in accordance with pre-existing theories. The effectiveness given the theory of experiential learning models in the art lessons of class V B. In this study do not use statistical figures.

\section{Researcher's Presence}

The position of researchers as a key instrument / main in this study, means that researchers acted fully as active participation in collecting data, and classifying data. So that the presence of researchers is absolutely necessary. The status of the researcher is known by the subject or informant. Data collection activities are carried out repeatedly. Start from the preliminary research stage, from learning to after learning, an experience-based model is used.

\section{Research sites}

In this study the researchers chose SD Inpres 5/81 Bajoe as a research location because it is one of the schools that applied the Education Unit Level Curriculum in 2006, to find out the process of learning arts and culture (music) with experiential learning models.

\section{Data source}

The data sources in this study are the principal, guardians of class V B, and students of class V B of SD Inpres 5/81 Bajoe. The type of data obtained by expressions of students, teachers or principals using interviews, student feelings and experiences / observations of teachers using questionnaires, learning outcomes (skills) using embar motoric observation and learning process simulation and alerting using teacher and student observation sheets. 
So that researchers can collect data that is validity and reliability can be accounted for related to learning cultural arts and skills (music art) in class V B SD Inpres 5/81 Bajoe. Then the data captured using the snowball technique (snowball sampling) conducted by researchers with teachers and principals. To capture student data conducted by researchers with the help of teachers and to capture teacher data conducted by researchers with the help of the principal.

\section{Data Collection Procedure}

Data collection procedure is the stage carried out in obtaining data. The data obtained can be said to be valid or legitimate if it first goes through the stage of taking data from information that is not yet scientific. In this study gathering information through questionnaires, observations, interviews, and documentation.

\section{Questionnaire Technique}

Data collection techniques are carried out directly by sharing some questions or statements.

\section{Observation Techniques}

Data collection techniques were carried out directly in the process of learning arts and culture (music) in class V B SD Inpres 5/81 Bajoe, when the teacher taught and students learned. In this study, researchers used a Non-participation observer research that researchers were not directly involved in group activities, or researchers only acted as observers who did not participate in the activities they observed. Unstructured observations to provide greater flexibility to the observer regarding the timing or environmental conditions of the observations.

\section{Interview Technique}

Data collection techniques are done by face-to-face process between two people to obtain information from related information sources. In this study, researchers used structuredstructured interviews that is the interviewer (researcher) compiled in detail and systemized research instruments in the form of written questions. This technique is applied to the principal of SD Inpres 5/81 Bajoe, homeroom teacher and grade V students of SD B Inpres 5/81 Bajoe, Tanete Riattang Timur District, Bone Regency.

\section{Documentation Techniques}

Researchers investigate written objects such as books, documents, minutes of meetings, and so on. The documents in this study relate to the learning of art and culture and skills (music art) grade $\mathrm{V}$ students of SD Inpres 5/81 Bajoe using experiential learning models. Such as syllabus, lesson plans, photographs and other works of art. This technique can strengthen the data obtained by the existence of evidence from the learning device that is a reference in the teaching and learning process.

\section{Discussion}

\subsection{Preliminary Research}

\section{School Conditions}

Research at SD Inpres 5/81 Bajoe Tanete Riattang Timur District Bone District especially in Class V B SD SD Inpres 5/81 Bajoe on arts and culture (SBK) subjects. This school is located 
on Jalan Laksamana Yos Sudarso which consists of 6 classrooms, 1 principal's room, 1 teacher's room, 1 library, 1 canteen and 1 UKS room and Prayer room.

\section{School Music Arts Facility}

SD Inpres 5/81 Bajoe, Tanete Riattang Timur District, Bone Regency is a concern because of the lack of facilities that can support art learning. Drum and rattles used during learning are the efforts of the teacher by borrowing from other agencies for the achievement of learning objectives. In addition to musical instruments can support the development of student talent, there needs to be a special room for the arts, namely the Art Laboratory. However, after the results of the interview that which is an obstacle to the existence of building assistance at this elementary school is the lack of adequate locations that are fairly narrow. So that the school is only able to teach the art of music in accordance with its abilities such as the procurement of musical instruments from other agencies.

\section{Data collection}

Observation Results

\section{Students}

The first meeting, students are still not focused on learning because there are still disturbing each other with $72 \%$ done. In addition, there is no group work done so that the social spirit of students is still lacking. Students still look bigung with the lessons given causing the students' ability to think to be hampered. In the next meeting, it was seen that students had started to organize in the lesson with $80 \%$ conducted. Improved learning even though students are still less active in learning, but there is already a social spirit that is formed from group work with $88 \%$ being done. The third meeting, students are very enthusiastic in learning because they already understand and master the lessons given by the teacher. Based on the observation sheet of 25 criteria that were observed up to only 1 criteria that were not carried out with a percentage of $96 \%$ criteria that were done and $0.4 \%$ that were not. So that it can be categorized as active students in learning.

\section{Teachers}

The first meeting, the teacher did not give students the opportunity to participate actively in learning because of the lack of motivation and appreciation given by the teacher and the absence of group work done with $80 \%$ done. In the next meeting, the teacher began to motivate students and involved themselves in group work with $88 \%$ being done. The teacher gives students the opportunity to actively think about melodic and rhythmic music material with $92 \%$ being done. The teacher does not provide the opportunity to ask questions challenging. However, learning has been seen to be active because of high student enthusiasm with $96 \%$ indicators done.

\subsection{Questionnaire Results}

1. Students

Student responses from the questionnaire revealed that students enjoyed learning by direct practice. They agree with experiential learning that emphasizes motor skills in accordance with 
the basic principles of music art material. Of the 39 students there were $93.5 \%$ who agreed that learning practical music art material was easier to understand and master. And $6.5 \%$ disagree. So from these data can be stated effective experiential learning model in learning the art of music in class $\mathrm{V}$ B.

\section{Teacher}

The teacher's response states that the experiential learning model is effectively used on material that emphasizes students' motor skills. So he often uses the model in SBK materials, especially music. Based on the questionnaire filled with the percentage of teachers agreeing to $92.5 \%$ and the percentage disagreeing with the model which is $7.5 \%$. So it can be said that experiential learning models are in demand because of the high level of usefulness in SBK subjects.

\section{Learning Activities}

a. Preparation

Preparations made in this study are fairly simple because students only carry musical instruments. Unlike other material that requires a lot of preparation in teaching. In order to realize more creative and diverse learning, the school prepares a musical instrument for rattles and drums:

Drum is a rhythmic musical instrument, meaning a musical instrument that is not pitched. This instrument is provided by the school. The availability of the drum gives consideration that if the students who give the assignment to provide it will be burdensome because in different financial matters. Drum is used interchangeably, depending on the systematic group.

Rattles are rhythmic musical instruments. As a musical instrument is not pitched means it is quite easy to play depending on the beats needed. This instrument is provided by the school, the reason is that this instrument can be used interchangeably easily and is able to be provided by the school. Before practice, the teacher gives an explanation of how to use it. So after knowing the students become more interested in using it.

The recorder is one of the melodic musical instruments. As a musical instrument that means it requires considerable time in using it. The theory in playing this instrument is very necessary. The reason is that the recorder has its own pitch, which must be played in the acquisition of a particular note. Initially the students did not know how to use some holes which when closed with fingers produce a certain tone. However, after the teacher gives an explanation and students play it, then produce music with tones that make up the song lyrics. The explanation is not only in the form of theory, but it appears from the guidance given by the teacher. The students' enthusiasm was very good because they seemed to be curious about how to use the instrument correctly.

Pianika as a melodic musical instrument prepared by students. The principle pianika works is a combination of piano and flute. In addition to pressing, blowing can also produce a tone. This instrument is quite difficult because it has many parts of the tone, ranging from low, standard to high. The resulting tone can form the lyrics to the song. Students look enthusiastic playing it after getting an explanation from the teacher. At first the students seemed confused by the way they were used, but after they learned it they looked very proud of their work and sincerity. 


\section{b. Preliminary activities}

The preliminary activities aim to create an atmosphere of initial affective learning and enable students to follow the learning well in accordance with the results of observation. When starting learning, the teacher greets students with enthusiasm and excitement (saying greetings), checking class cleanliness and giving input to students on duty that day, students pray led by their class leader and all students and teachers follow, after praying students sing wrong one national compulsory song with a loud and clear voice, then check the attendance of students and ask for the absence of students if there is no attendance. Experiental learning model in the preliminary activity is to strengthen students' understanding of the concepts that have been mastered relating to new subject matter that is will be studied by students.

Apperception activities conducted by the teacher to determine the extent of student knowledge about rhythmic and melodic musical instruments the teacher asks students to observe the sounds they produce. Students look enthusiastic about the observer process, it appears that students pay attention to the teacher's explanation and are very curious to use the instrument.

\section{c. Core activities}

The core activity in learning is a process of forming students' experiences and abilities in a programmatic manner which is carried out within a certain time duration. The core activities in the experiential learning model are aimed at constructing concepts, laws or principles by students with the help of the teacher through the steps of the activities given at the beginning of learning. The experiential learning model is the teacher explaining and delivering the material through the stages of real experience, reflection observation phase, conceptualization stage, and implementation.

\section{d. Real experience stage}

Learning at the real experience stage, students are given examples of musical instruments such as drums. Initially the teacher gives an apperception about the drum instrument, then students directly observe or feel how the drum instrument was previously only theoretical from the teacher's explanation. Seen for the ability of students to use musical instruments, but with the direction and guidance of the teacher makes the enthusiasm for student learning increases.

Students actively participate in learning with experiential learning models. Groups one and two are given the opportunity to play the musical instruments they carry. It turns out, of the two groups there is an interesting thing that is the musical instrument is uniformly one type of musical instrument. Group one used a pianica instrument and group two used a musical instrument recorder. Then the teacher provides opportunities for students to observe the differences that occur. One thing that arises is that it sounds united with one another, but still the need for aesthetic level because of the diversity of musical instruments is quite important in singing songs. Initially students consider the uniformity that occurs to make the music produced better heard. However, after combining the drum, pianica, recorder and rattles, the resulting music sounds more assertive and meaningful. The reason is the combination of melodic and rhythmic music is a complementary unity because of the musical instruments that are pitched and not pitched making the music produced sounds more meaningful and more soulful. 


\section{e. Conceptualization stage}

Students are assigned by the teacher to discuss together with friends who have formed groups. The teacher gives an assignment to discuss the definitions of melodic and rhythmic instruments, the differences between melodic and rhythmic instruments. Conceptualization activities examine either individually or in groups. Students discuss with fellow group members. But the attitude that is instilled in this discussion is to respect opinions among students. Students have the opportunity to express their opinions. But in reality there are still students who hesitate to issue their opinions melodic and rhythmic musical instruments. This review activity will develop communication skills. When in fact some students do not respond to the assignments given by the teacher. The teacher always reminds students to discuss with classmates.

\section{f. Implementation}

The teacher makes assignments for students to play music together. This implementation phase makes students look happy because they already know how to use musical instruments and are able to play certain songs. Various kinds of musical instruments they already know both in theory and practice. This stage emphasizes more on the practice as a result of some of the previous stages and is the stage that students like most, although there are still some people who need guidance and practice more often. The activity carried out is the final stage which forms a form of evaluation for teachers to find out how many students still need guidance. Students are active and enthusiastic about learning with the material that has been delivered. Even though they work together, this actually shapes the character of students by respecting the opinions of the theme. This group division is shared by the teacher. So that the distribution becomes even. All groups have six or seven people, because there are 39 students in class V B. This of course makes the number of group members evenly distributed. According to the teacher, do this because it will not cause a commotion or blame among group members, regarding the division of group members.

\section{g. Closing activities}

Closing activities are aimed at two main points. First, validation of concepts, laws or principles that are known to students. Second, the enrichment of subject matter mastered by students. Validation can be done to identify the truth of the concepts that have been given to students. Often teachers ask students to express concepts they already know. Based on this, it can be seen whether or not there is a concept error. If there is then the teacher can immediately correct the concept errors.

Enrichment can be done by giving assignments to students to read textbooks or other sources of information to strengthen understanding of the material that has been given. The teacher also asks students to access resources from the internet in the form of photos or videos relating to the material that has been given. Enrichment can also be done by asking students to do experiments related to the material that has been given which is safe to do at home. The teacher reflects or concludes the results of lessons about rhythmic and melodic musical instruments together with students. Closing activities should the teacher conduct oral or written tests on students. But in this case the teacher does not provide oral tests in the form of questions or written tests in the form of questions that must be answered by students. Every work or task of playing a musical instrument performed by students is observed by the teacher. Whether it's 
already advanced or not. Because the teacher will assess the work of students in groups. So the teacher assesses students based only on their skills.

\subsection{Post-Research Evaluation}

Evaluation to measure success becomes one of the data in this study. the tool used is the student motor observation sheet with indicators that have been determined so that students' skills can be expressed as good, inadequate or sufficient. So that when students are declared good it will linearly support the description of learning done by the teacher. Of the 39 students who have mastered the use of musical instruments, 27 students $69.2 \%$, drum. 23 students 59\%, pianics 23 students $59 \%$, and recorders 18 students $46.1 \%$. As for students who have mastered the four musical instruments there are 9 students $23 \%$. Of the four musical instruments that are very difficult to understand and be mastered by students, namely recorders because only 18 students $46.1 \%$ master the attitudes and ways of using them. Meanwhile, the musical instrument that is most easily played by students is the drum because 23 students $59 \%$ are able to play with the right attitude.

\section{Discussion}

Regarding the results of research in Class V B SD Inpres 5/81 Bajoe, Tanete Riattang Timur District, Bone Regency through a number of data collection techniques, shows that the results of the analysis of learning arts and culture with experiential learning models are in good category. Student learning achievements in Class V B SD Inpres 5/81 Bajoe, Tanete Riattang Timur District, Bone, obtained through observation techniques, questionnaires, interview techniques, and techniques show that students are in good category.

The results of this study show that learning activities in Class V B with experiential learning models begin with preliminary activities, the teacher really conditions students to calm down and also focus first to pay attention to what is learned in arts and culture subjects and skills. The next learning activity is a core activity. This core activity in the experiential learning model uses the real experience stage, the reflection observation stage, the conceptualization stage, and the implementation. For more details, researchers describe these core activities one by one.

\section{Real experience}

Real experience is done by directing students to listen, listen, and see. The teacher chooses to invite students to observe examples of types of musical instruments, especially those classified as rhythmic and melodic.

2. Observation Reflection

This reflection observation activity with students who submit statements or questions about the information they have, from what is observed through a musical instrument that is shown when the teacher explains. Students make observations in order to get additional information, about learning the art of music especially rhythmic and melodic musical instruments.

3. Conceptualization

This conceptualization stage is gathering information. Students are required to gather information about rhythmic and melodic musical instruments by looking for differences from 
the two types of musical instruments. The aim is that students develop a conscientious attitude, and also respect the opinions of others.

4. Implementation

The implementation phase is carried out by students to see the level of ability to use students' musical instruments. The implementation phase allows the teacher to direct students in creating musical art. The teacher also guides the path of the music game that is done simultaneously. Students who do not play music are immediately reprimanded by the teacher or directed how to use it when there are still those who do not know. This stage also gives an effect that becomes active learning. Seen from the previous stages of learning is still less active because of the nature of learning that is still mingled between theories in the form of explanations and practices carried out by the teacher as a form of demonstration. So that at the implementation stage students are very happy and eager to play music in accordance with the manner of use that has been demonstrated by the teacher.

The four stages of the experiential learning model previously described require measurement of its effectiveness. The assessment sheet provides an overview of the results during the study. During the study both from the attitude to how to use musical instruments have been assessed with a variety of criteria so that the teacher can be declared good in teaching Culture Arts and Skills (SBK) specifically the art of music. In addition to observing the level of student skills there is an implementation process that already exists on the student and teacher observation sheets which explains the attitude of students and teachers during learning starting to the end.

\section{Conclusion}

Based on the results of research and discussion, it can be concluded that learning Cultural Arts and Skills (SBK) with experiential learning models in VB Class SD Inpres Tanete Riattang Timur District Bone is relatively good (effective), after reviewing the research objectives in accordance with the preparation, implementation, and learning outcomes in the form of evaluations obtained by students in learning arts and culture and skills (SBK) with experiential learning model steps.

\section{References}

[1] Susanto dan Ahmad, Teori Belajar dan Pembelajaran di Sekolah Dasar. Jakarta: Kencana, 2013.

[2] Paryanto, Joko, Ambar Widyaningtyas, dan Sri Murni, Kontribusi Pengelolaan Laboratorium dan Motivasi Belajar Siswa terhadap Efekivitas Proses Pembelajaran. Surakarta: Mediama, 2010.

[3] Naisah, "Pembelajaran Seni Budaya dan Keterampilan dengan Menggunakan Pendekatan Inkuiri di Sekolah Dasar.” Universitas TanjungPura Pontianak, Pontianak, 2013.

[4] Uno, Hamzah B, dan Nurdin Mohammad, Belajar dengan Pendekatan Paikem: Pembelajaran Aktif, Inovatif, Lingkungan, Kreatif, Menarik. Jakarta: PT Bumi Akasar, 2015.

[5] M. M. Mosal, “Analisis Efektivitas, Kontribusi Pajak Parkir Terhadap Pendapatan Asli Daerah (PAD) Dan Penerapan Akuntansi Di Kota Manado," Jurnal EMBA: Jurnal Riset Ekonomi, Manajemen, Bisnis dan Akuntansi, vol. 1, no. 4, 2013. 
[6] B. Rifa'i, "Efektivitas Pemberdayaan Usaha Mikro Kecil dan Menengah ( UMKM ) Krupuk Ikan dalam Program Pengembangan Labsite Pemberdayaan Masyarakat Desa Kedung Rejo Kecamatan Jabon Kabupaten Sidoarjo," Kebijakan dan Manajemen Publik, vol. 1, no. 1, hlm. 130-136, 2013.

[7] N. R. Novianti, "Kontribusi pengelolaan laboratorium dan motivasi belajar siswa terhadap efektivitas proses pembelajaran," Jurnal Pendidikan MIPA. Edisi khusus, vol. 1, hlm. 158-166, 2011.

[8] Fathurrohman dan Muhammad, Model-model Pembelajaran Inovatif. Yogyakarta: ArRuzz Media, 2015.

[9] Silberman dan Mel, Experienal Learning. Bandung: Nusamedia, 2014.

[10] Majid dan Abdul, Strategi pembelajaran. Bandung: Remaja Rosdakarya, 2017.

[11] Rusman, Model-Model Pembelajaran Mengembangkan Profesionalisme Guru. Jakarta: Rajawali Pers, 2016.

[12] Susilawandi, "Pembelajaran Seni dan Prakarya dengan Pendekatan Saintifik Siswa Kelas V SD Negeri 13 Biru Kecamatan Tanete Riattang Kabupaten Bone," Universitas Negeri Makassar, Makassar, 2017.

[13] Taupik dan Nur, "Hubungan Antara Penguasaan Teori Musik dengan Prestasi Belajar Bermain Ansambel Musik pada Siswa SMP Negeri 2 Yogyakarta,” Universitas Negeri Yogyakarta, Yogyakarta, 2014.

[14] Desyanri, "Pembelajaran Pendidikan Seni Musik di Sekolah Dasar," 2018. . 